\title{
Razlike u školskom uspjehu učenika osnovne škole s obzirom na pohađanje programa produženog boravka
}

Ivana Olujić*

iolujic81@gmail.com

https://orcid.org/0000-0002-6387-3541

Nevenka Maras ${ }^{* * *}$

Nevenka871@gmail.com

http://orcid.org/0000-0001-5057-7164 https://doi.org/10.31192/np.19.2.8

UDK: 373.3.091.31:37.091.212.5 Izvorni znanstveni rad / Original scientific paper

Primljeno: 20. studenog 2020.

Prihvaćeno: 14. siječnja 2021.

Cilj ovog istraživanja bio je utvrditi razlike u školskom uspjehu učenika s obzirom na pohađanje produženog boravka. Istraživanjem je obuhvaćeno 386 učenika (N=386) prvih pet razreda Osnovne škole Većeslava Holjevca u Zagrebu. Korišten je sekundaran izvor podataka, odnosno rad na pedagoškoj dokumentaciji. Korištene su ocjene iz hrvatskog jezika, matematike i prosjek svih ocjena na kraju školske godine 2017./2018. te podaci o pohađanju produženog boravka. Rezultati istraživanja ukazuju na to da učenici koji prva tri razreda pohađaju produženi boravak postižu statistički značajno bolje ocjene iz hrvatskog ( $p=$ $0,00)$, matematike $(p=0,03)$ i bolji prosjek ocjena $(p=0,00)$, nego učenici koji ne idu u boravak. Nadalje, rezultati upućuju na to da učenici koji su pohadali boravak, bolje ocjene zadržavaju i u četvrtom te petom razredu. Dobiveni rezultati svakako potiču na promišljanje o dostupnosti programa produženog boravka svim učenicima koji to žele, neovisno o zaposlenosti njihovih roditelja.

Ključne riječi: ocjene, osnovna škola, produženi boravak, školski uspjeh, učenici.

\footnotetext{
* Ivana Olujić, prof., Ministarstvo znanosti i obrazovanja, Donje Svetice 38, HR-10000 Zagreb.

**Doc. dr. sc. Nevenka Maras, Sveučilište u Zagrebu, Učiteljski fakultet, Savska cesta 77, HR10000 Zagreb.
} 


\section{Uvod}

Školski uspjeh svakog pojedinog učenika (riječ učenik u ovom radu jednako se odnosi na učenik i učenica) kao aktivnog dionika obrazovnog procesa, uvjetovan je cijelim nizom čimbenika. Iako bi usvojeno znanje učenika, kao jedan od ciljeva obrazovanja, trebalo biti osnovni pokazatelj uspješnosti učenika, u našem obrazovnom sustavu tu ulogu najčešće preuzima školski uspjeh, odnosno završne ocjene na kraju školske godine. Završne ocjene su jako značajne učenicima i njihovim roditeljima jer o njima ovisi daljnji tijek školovanja, usmjerenje, izbor životnog zanimanja te u konačnici, životni uspjeh i ostvarenje pojedinca. S obzirom na to da su u obrazovnom sustavu Republike Hrvatske ocjene mjerilo školskog uspjeha, $\mathrm{u}$ tom smislu će se on razmatrati i u ovom radu.

Školski se uspjeh poistovjećuje s napretkom u učenju, apostrofirajući potrebu za personalizacijom učenja koje bi se trebalo oslanjati na uvažavanje pojedinca jer optimalan način učenja ne može biti prikladan za svakog učenika posebno. ${ }^{1}$ Pri tom je svakako važno naglasiti socijalne vještine koje se razlikuju od učenika do učenika te samoprocjenu vlastitih socijalnih vještina koja, ako je pozitivna, pozitivno će djelovati i na školski uspjeh učenik. ${ }^{2}$ Školski uspjeh bit će bolji i kada se učenje odvija u pozitivnoj atmosferi, u učionici u kojoj se učenici osjećaju ugodno, sigurno i sretno. ${ }^{3}$

Iako bi smisao i misija obrazovnog sustava trebalo biti odrastanje mladih u zdrave i kvalitetne osobe, ${ }^{4} \mathrm{u}$ našem je obrazovnom sustavu od krucijalne važnosti upravo školski uspjeh, jer neuspjeh učenika, neuspjeh je njegovih nastavnika, škole i roditelja, ${ }^{5}$ a posljedično i neuspjeh obitelji koja također trpi posljedice školskog neuspjeha učenika.

Zaključne ocjene i školski uspjeh na kraju godine vodeće su mjerilo kvalitete rada i izvršavanja školskih obaveza tijekom nastavne godine. ${ }^{6} \mathrm{O}$ školskom uspjehu učenika ovisi i uspjeh škole i njenih nastavnika, ali i uspjeh te zadovoljstvo obitelji samog učenika.

${ }^{1}$ Usp. Školski uspjeh, u: Ivan MARIJANOVIĆ, Leksikon odgojno-obrazovnih znanosti, Zagreb, Akademija odgojno-obrazovnih znanosti Hrvatske, 2017, 1190.

${ }^{2}$ Usp. V. BULJUBAŠIĆ KUZMANOVIĆ, T. BOTIĆ, Odnos školskog uspjeha i socijalnih vještina kod učenika osnovne škole, Život i škola, 58 (2012) 27, 38-54, 38.

${ }^{3}$ Usp. Z. RABOTEG-ŠARIĆ, M. ŠAKIĆ, A. BRAJŠA-ŽGANEC, Kvaliteta života u osnovnoj školi: povezanost sa školskim uspjehom, motivacijom i ponašanjem učenika, Društvena istraživanja, 18 (2009) 4-5, 697-716, 699.

${ }^{4}$ Usp. Z. BREBRIĆ, Neke komponente emocionalne inteligencije, školski uspjeh, prosocijalno i agresivno ponašanja učenika u primarnom obrazovanju, Napredak, 149 (2008) 3, 296-311, 297.

${ }^{5}$ Usp. V. BILIĆ, Uzroci, posljedice i prevladavanje školskog neuspjeha, Zagreb, Hrvatski pedagoško-književni zbor, 2001, 211-212.

${ }^{6}$ Usp. B. JOKIĆ, Z. RISTIĆ DEDIĆ, Razlike u školskom uspjehu učenika trećih i sedmih razreda osnovnih škola u Republici Hrvatskoj s obzirom na spol učenika i obrazovanje roditelja. Populacijska perspektiva, Revija za socijalnu politiku, 17 (2010) 3, 345-362, 347. 


\section{1. Čimbenici školskog uspjeha}

Polazeći od osobina učenika, kao čimbenika školskog uspjeha, ranija istraživanja odnosila su se najviše na učenikovu inteligenciju, motivaciju, spol te karakteristike ličnosti. Što se tiče inteligencije, znanstvenici su u svojim istraživanjima složni oko njene izrazite povezanosti sa školskim uspjehom. ${ }^{7}$ Rezultati istraživanja povezanosti opće inteligencije i dimenzija ličnosti sa školskim postignućem pokazuju da dimenzije ličnosti u kasnijim fazama školovanja preuzimaju značajniju ulogu u odnosu na inteligenciju koja je na razini osnovne škole jači prediktor školskog uspjeha. Od dimenzija ličnosti (neuroticizam, ekstraverzija, otvorenost prema iskustvu, ugodnost i savjesnost), prema tom istraživanju, savjesnost ima najveći pojedinačni prediktivni utjecaj, što ne čudi s obzirom na njenu povezanost $\mathrm{s}$ radnim navikama i organiziranošću. ${ }^{8}$

Istraživanje o doprinosu učeničkog temperamenta i interpersonalnog ponašanja nastavnika u objašnjavanju samopoštovanja i školskog uspjeha učenika ${ }^{9}$ pokazalo je da učenički temperament, ali i nastavničko interpersonalno ponašanje imaju značajnu ulogu u objašnjenju samopoštovanja i školskog uspjeha, a kao najjači prediktor školskog uspjeha istakla se samokontrola.

Pored inteligencije i dimenzija ličnosti, znanstvena istraživanja o uspjehu učenika obuhvaćala su i razlike uvjetovane spolom. Da na školski uspjeh utječe i spol učenika, u našem obrazovnom sustavu posebno se zamjećuje u hrvatskom i engleskom jeziku, u kojima učenice postižu značajno bolje rezultate od učenika. Zamjetno je da bolje rezultate učenice postižu iz predmeta koje većinom predaju učiteljice (hrvatski, engleski), dok dječaci bolji uspjeh od djevojčica postižu iz predmeta koje s nešto većom zastupljenošću predaju učitelji. ${ }^{10}$ No, kad je spol u pitanju, valja istaknuti da školske ocjene ovise i o osobnom dojmu učitelja, a on je često uvjetovan i ponašanjem učenika. Time su djevojčice, na neki način, u povoljnijem položaju jer su u prosjeku primjerenijeg ponašanja od dječaka. ${ }^{11}$

Kad je u pitanju socio-ekonomski status (SES) učenika, istraživanja ukazuju na to da djeca iz siromašnijih obitelji, niskog socio-ekonomskog statusa postižu lošije rezultate u školi, u odnosu na djecu boljeg SES-a. Promatrajući obrazov-

7 Usp. I. J. DEARY i dr., Intelligence and Educational Achievement, Intelligence, 35 (2007) 1, 13 $21,13$.

${ }^{8}$ Usp. Matešić, Zarevski, Povezanost opće inteligencije i dimenzija ličnosti..., 260.

9 Usp. S. ŠIMIĆ ŠAŠIĆ, Doprinos učeničkog temperamenta i interpersonalnog ponašanja nastavnika u objašnjenju samopoštovanja i školskog uspjeha učenika, Školski vjesnik: časopis za pedagogijsku teoriju i praksu, 66 (2017) 3, 403-422, 403, 413.

${ }^{10}$ Usp. T. BABAROVIĆ, J. BURUŠIĆ, M. ŠAKIĆ, Uspješnost predviđanja obrazovnih postignuća učenika osnovnih škola Republike Hrvatske, Društvena istraživanja, 18 (2009) 4-5, 673-695, 686.

${ }^{11}$ Usp. T. BABAROVIĆ, J. BURUŠIĆ, M. ŠAKIĆ, Psihosocijalne i obrazovne odrednice školskog uspjeha učenika osnovnih škola. Dosezi dosadašnjih istraživanja, Suvremena psihologija, 13 (2010) 2, 235-256, 238. 
ni statusa roditelja u osnovnim školama u Republici Hrvatskoj, istraživanja upućuju na to da, što je razina obrazovanja roditelja veća, vjerojatnije je da će biti bolji školski uspjeh i njihova djeteta. Iako je obrazovanje obaju roditelja značajan čimbenik, obrazovanje majke je nešto dominantniji faktor koji utječe na školski uspjeh, a to se može obrazložiti tradicionalno intenzivnijom angažiranošću majke u procesu obrazovanja djeteta od njegove najranije dobi. ${ }^{12}$ Iako djeca obrazovanijih majki postižu bolji školski uspjeh, njemu najviše doprinosi izravna uključenost majke u obrazovanje vlastitog djeteta, pri čemu je manje važno njeno obrazovanje, kao i razred koji dijete pohađa. ${ }^{13}$

Analizirajući odnos veličine škole prema školskom uspjehu učenika, moglo bi se reći i da veličina škole može imati utjecaja na školski uspjeh, a međuljudski odnosi kvalitetniji su u manjim školama. ${ }^{14}$ Pri tome se misli na broj učenika jer, gdje ih je manje, lakše se razvijaju prisniji međuljudski odnosi te su učitelji u mogućnost bolje upoznati svoje učenike i posvetiti im se individualno.

Kod nas manje škole uglavnom postoje u ruralnim i raseljenim sredinama gdje je i dostupnost dodatnih obrazovnih sadržaja učenicima manja, a u takvim sredinama, zbog intenzivnih iseljavanja, manji je i udio stanovništva s većom razinom obrazovanja, a već je navedeno da obrazovanje roditelja utječe na školski uspjeh djece.

Istraživanja pokazuju da školski uspjeh može biti značajno povezan i s obilježjima same škole. ${ }^{15}$ Promatrajući osobine učitelja, profesionalno iskustvo, odnosno duljinu učiteljskog radnog staža, oni su uglavnom pozitivno povezani $\mathrm{s}$ učeničkim uspjehom. S obzirom na to da su neki od navedenih prediktora školskog uspjeha međusobno povezani, negdje oko 40 do $45 \%$ njegovog varijabiliteta, treba objasniti nekim drugim čimbenicima. ${ }^{16}$

Cilj ovog istraživanja bio je ispitati povezanost pohađanja produženog boravka i školskog uspjeha učenika.

\section{Program produženog boravka}

U osnovnim školama Republike Hrvatske produženi boravak, kao poseban oblik odgojno-obrazovnoga rada, s obzirom na zaposlenost roditelja i moderno radno vrijeme, pohađa sve više učenika. Prijašnjih godina je on bio dostupan

${ }^{12}$ Usp. Babarović, Burušić, Šakić, Uspješnost predviđanja..., 679.

${ }^{13}$ Usp. M. BEDENIKOVIĆ, Uloga majke u školskom uspjehu djeteta, Školski vjesnik, 58 (2009) 3, 331-344, 340.

${ }^{14}$ Usp. V. E. LEE, S. LEOB, School Size in Chicago Elementary Schools. Effects on Teachers' Attitudes and Students' Achievement, American Educational Research Journal, 37 (2000) 1, 3-31, 6.

${ }^{15}$ Usp. A. SUTTON, I. SODERSTORM, Predicting Elementary and Secondary School Achievement with School-Related and Demographic Factors, The Journal of Educational Research, 92 (2001) 6, 332.

${ }^{16}$ Usp. Babarović, Burušić, Šakić, Psihosocijalne i obrazovne odrednice školskog uspjeha..., 246. 
samo u većim, razvijenim gradovima i urbanim sredinama, a sada svjedočimo tendenciji organizacije produženog boravka i u osnovnim školama manjih i ruralnih sredina.

Program produženog boravka $u$ našim osnovnim školama organiziran je temeljem Zakona o odgoju i obrazovanju u osnovnoj i srednjoj školi ${ }^{17}$ te Pravilnika o organizaciji i provedbi produženog boravka u osnovnoj školi, ${ }^{18}$ a njegova provedba zakonski je regulirana 2018. godine.

Začeci produženog boravka sežu u šezdesete godine prošlog stoljeća i prvo je bio vezan za učenike bez nadzora roditelja, s problematičnim ponašanjem i poteškoćama u učenju. ${ }^{19}$ Kasnije je postao praktično i korisno rješenje za skrb o djeci nižih razreda u vrijeme dok su im roditelji na radnome mjestu.

Prijašnja istraživanja koja su se ticala produženog boravka u našim školama uglavnom su bila fokusirana na učitelje zaposlene u njemu, odnosno na njihove stavove o toj vrsti odgojno-obrazovnog rada te njihovo zadovoljstvo radom $\mathrm{u}$ produženom boravku. Većina ih je bila negativnog stava o cjelodnevnom boravku učenika u školi te su smatrali da kao učitelji nisu dovoljno osposobljeni za takvu vrstu rada. Kao razloge nezadovoljstva radom u boravku, između ostalog, navodili su organizacijske probleme, neravnopravan položaj u odnosu na kolege $u$ redovnoj nastavi i većina njih izjasnila se da bi radije radila u redovnoj nastavi. ${ }^{20}$

Za učitelje u boravku od velike je važnosti kvalitetna suradnja, kako s učenicima tako i s roditeljima, da boravak ne bi bio samo »čuvanje« djece i obavljanje domaćih zadaća. ${ }^{21}$

Rezultati empirijskog istraživanja

"pokazuju da u provođenju cjelodnevnog boravka u osnovnim školama ima i teškoća: nedostatak školskog prostora, nastavne opreme, financijskih sredstava, nedovoljna osposobljenost učitelja za takvu organizaciju odgojno obrazovnog rada. Iako se navedene teškoće ne mogu zanemariti, rezultati istraživanja pokazuju da cjelodnevni boravak u osnovnim školama (posebice u razrednoj nastavi) treba i dalje organizirati ${ }^{22}$

Rezultati ovog istraživanja mogu biti korisni za buduću organizaciju boravka, ali i roditeljima za lakši izbor skrbi o djetetu prilikom polaska u prvi razred.

\footnotetext{
${ }^{17}$ Usp. Ministarstvo znanosti i obrazovanja, Zakon o odgoju i obrazovanju...

${ }^{18}$ Usp. MINISTARSTVO ZNANOSTI I OBRAZOVANJA, Pravilnik o organizaciji i provedbi produženog boravka u osnovnoj školi, https://narodne-novine.nn.hr/clanci/sluzbeni/2019_06_62_1222.html (05.09.2020).

${ }^{19}$ Usp. K. DOUTLIK, Čimbenici zadovoljstva i nezadovoljstva učitelja radom u produženom boravku, Školski vjesnik, 60 (2011) 4, 427-443, 427.

${ }^{20}$ Usp. J. MARTINČEVIĆ, Utjecaj socijalne kompetencije učitelja na provođenje cjelodnevnog boravka učenika u školi, Odgojne znanosti, 12 (2010) 2, 441-458, 444-445.

${ }^{21}$ Usp. A. LOVRENTJEV, Škola koja voli mene 1, Zagreb, Naklada Divič, 2005, 144.

${ }^{22}$ S. VUČAK, Cjelodnevni boravak učenika u osnovnoj školi, Napredak, 136 (1995) 1, 51-56, 55.
} 


\section{Problem, cilj i hipoteze}

Cilj istraživanja bio je ustanoviti povezanost pohađanja produženog boravka tijekom prva tri razreda osnovne škole i školskog uspjeha učenika. Postavljeni su sljedeći problemi i hipoteze:

P1: Ispitati razliku u ocjenama na kraju školske godine iz hrvatskog jezika, matematike i prosjeka ocjena učenika koji u prva tri razreda pohađaju produženi boravak i njihovih vršnjaka koji ga ne pohađaju.

H1: Učenici prva tri razreda koji pohađaju produženi boravak, imaju bolje ocjene iz hrvatskog jezika, matematike i prosjek ocjena, nego oni učenici koji ga ne pohađaju.

P2: Ispitati razliku u ocjenama na kraju školske godine iz hrvatskog jezika, matematike i prosjeka ocjena učenika četvrtih i petih razreda koji su prva tri razreda pohađali produženi boravak i onih koji ga nisu pohađali.

H2: Učenici koji su pohađali boravak u prva tri razreda, imaju bolje ocjene iz hrvatskog jezika, matematike i prosjek ocjena u četvrtom i petom razredu, $u$ odnosu na vršnjake koji nisu išli u boravak.

Nezavisne varijable: razred, pohađanje produženog boravka (da/ne).

Zavisna varijabla: ocjena iz hrvatskog, matematike i prosjek ocjena.

\section{Metodologija istraživanja}

\subsection{Sudionici istraživanja}

Uzorak ispitanika: svi učenici prvih pet razreda Osnovne škole Većeslava Holjevca u Zagrebu, neovisno o tome jesu li pohađali boravak ili ne ( $\mathrm{N}=386)$. Po načinu uzorkovanja radi se o neprobabilističkom uzorku, a po vrsti, o prigodnom uzorku. Empirijsko istraživanje u navedenoj školi provedeno je na kraju školske godine 2017./2018. Rezultati su anonimni i povjerljivi, a korišteni su isključivo za izradu ovog rada. Rezultate nije moguće povezati s identitetom ispitanika. S obzirom na metodološki okvir istraživanja i način obrade podataka, riječ je o kvantitativnom, empirijskom istraživanju.

\subsection{Socio-demografske karakter ispitanika}

Istraživanjem su obuhvaćena 72 učenika prvih razreda (19\%), 84 učenika drugih (22\%), 82 učenika trećih (21\%), 84 učenika četvrtih (22\%) te 64 učenika petih razreda (17\%). S obzirom na pohađanje produženog boravka, veći udio ispitanih, njih 72,5\% (N=280) tijekom prva tri razreda pohađaju ili su pohađali produženi boravak, dok manji udio ispitanih, njih $27,5 \%(\mathrm{~N}=106)$ tijekom prva tri razreda ne pohađa ili nisu pohađali boravak. 


\subsection{Mjerni instrument}

Metoda prikupljanja podataka bila je rad na pedagoškoj dokumentaciji (podatcima iz e-matice), uz suglasnost ravnatelja škole. Korištene su ocjene iz pojedinih predmeta i prosjek ocjena na kraju školske godine. Za istraživanje nisu bili relevantni identitet niti bilo koji osobni podatci učenika, stoga nisu ni traženi. Prikupljeni su podatci o pet varijabli (razred u trenutku istraživanja: prvi, drugi, treći, četvrti ili peti, podatak je li učenik pohađao produženi boravak u prva tri razreda, završna ocjena iz matematike, hrvatskog jezika te prosjek ocjena na kraju analizirane školske godine).

\section{Rezultati}

Prikupljeni podaci obrađeni su i analizirani u statističkom programskom paketu SPSS-u $21^{23}$ metodama i postupcima deskriptivne te inferencijalne (induktivne) statistike. U okviru deskriptivne statistike navedeni su osnovni deskriptivni statistički pokazatelji (frekvencije, postotci, prosječne vrijednosti, modalne vrijednosti, medijalne vrijednosti, standardna devijacija, totalni raspon, asimetrija i spljoštenost) te su podaci dani u tabličnim prikazima. ${ }^{24}$ Varijable koje su mjerene ordinalnom ljestvicom procjene - ocjene, tretirane su kao kvantitativne varijable. S obzirom na to da sve kvantitativne varijable statistički značajno odstupaju od normalne distribucije, u okviru inferencijalne statistike, za testiranje statističke značajnosti razlika i povezanosti korišteni su neparametrijski testovi. Pri tome, u slučaju testiranja povezanosti kvalitativnih varijabli, korišten je Hi-kvadrat test, dok je povezanost kvantitativnih varijabli testirana Spearmanovim koeficijentom rang korelacije.

U slučaju testiranja statističke značajnosti, razlika pripadnika dviju skupina na kvantitativnoj varijabli korišten je Mann-Whitneyev U test, dok je u slučaju testiranja statističke značajnosti razlika pripadnika više skupina na kvantitativnoj varijabli korišten Kruskal Wallisov test. Radi testiranja normalnosti odabranih varijabli, korišten je Kolmogorov-Smirnov Z test. Svi su statistički testovi provedeni uz pet postotnu razinu rizika, statistički značajni $(\mathrm{p}<0,05)$.

\footnotetext{
${ }^{23}$ Statistical Package for the Social Sciences čija je besplatna demo verzija u trajanju od 21 dan preuzeta sa stranice proizvođača https://www.ibm.com/analytics/spss-trials.

${ }^{24}$ Zbog zaokruživanja decimalnih brojeva suma postotaka na pojedinim prikazima može biti veća ili manja od $100 \%$.
} 


\section{Rezultati za H1}

$\mathrm{Za}$ testiranje prve hipoteze, s obzirom na to da distribucije analiziranih zavisnih varijabli odstupaju statistički značajno od normalne distribucije, korišten je neparametrijski test, Mann-Whitneyev test za dva nezavisna uzorka, uz pet postotnu razinu rizika.

Tablica 1. Odabrani deskriptivni statistički pokazatelji analiziranih zavisnih varijabli učenika koji su u trenutku provođenja istraživanja završili prva tri razreda osnovne škole $(\mathrm{N}=238)$

\begin{tabular}{|c|c|c|c|c|c|c|c|c|}
\hline & 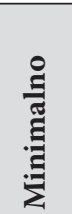 & 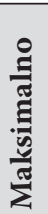 & $\mathbf{M}$ & SD & $\begin{array}{l}\text { K-S } \\
\text { test }\end{array}$ & $\mathbf{p}$ & 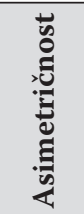 & 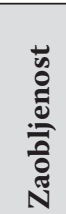 \\
\hline Matematika & 2 & 5 & 4,62 & 0,69 & 6,71 & $0,00^{*}$ & $-1,88$ & 2,93 \\
\hline $\begin{array}{c}\text { Hrvatski } \\
\text { jezik }\end{array}$ & 2 & 5 & 4,58 & 0,66 & 6,12 & $0,00^{*}$ & $-1,67$ & 2,91 \\
\hline $\begin{array}{c}\text { Prosjek } \\
\text { ocjena }\end{array}$ & 3,71 & 5 & 4,84 & 0,26 & 4,57 & $0,00^{*}$ & $-1,99$ & 3,80 \\
\hline
\end{tabular}

Legenda: $\mathrm{M}$ - aritmetička sredina; SD - standardna devijacija; K-S test - koeficijent Kolmogorov-Smirnovljeva $\mathrm{Z}$ testa; $\mathrm{p}$ - razina statističke značajnosti Kolmogorov-Smirnovljeva testa; * - statistički značajan koeficijent na razini značajnosti $p<0,05$, Asimetričnost koeficijent simetričnosti distribucije rezultata; Zaobljenost - koeficijent oblika distribucije rezultata

Koristeći Mann-Whitneyev test za dva nezavisna uzorka, uz pet postotnu razinu rizika, testirano je postojanje statistički značajnih razlika u referentnim ocjenama između učenika prva tri razreda osnovne škole koji pohađaju boravak te onih koji ne pohađaju. Utvrđeno je da se učenici prva tri razreda osnovne škole koji pohađaju boravak statistički značajno razlikuju od onih koji ne pohađaju, pri čemu učenici prva tri razreda osnovne škole koji pohađaju boravak, na kraju školske godine postižu bolje ocjene iz hrvatskog (Mann-Whitney $U=3570,00$; $\mathrm{p}=0,00$ ), iz matematike (Mann-Whitney $\mathrm{U}=4308,50 ; \mathrm{p}=0,03$ ) te postižu bolji prosjek ocjena na kraju školske godine (Mann-Whitney $U=3509,00 ; p=0,00$ ).

Na razini statističke značajnosti od 0,05 utvrđeno je da se učenici prva tri razreda koji pohađaju boravak te oni koji ga ne pohađaju, statistički značajno razlikuju u ocjenama na kraju školske godine iz hrvatskog $(\mathrm{p}=0,00)$, matematike $(\mathrm{p}=0,03)$ i prosjeka ocjena $(\mathrm{p}=0,00)$. Usporedbom rangova analiziranih skupina, vidljivo je da učenici prva tri razreda koji pohađaju boravak imaju bolje ocjene iz hrvatskog i matematike te bolji prosjek ocjena na kraju školske godine, dok oni koji ne pohađaju boravak imaju lošije ocjene iz hrvatskog i matematike te lošiji prosjek ocjena na kraju školske godine. 


\section{Rezultati za H2}

Za potrebu testiranja druge hipoteze, s obzirom na to da distribucije analiziranih zavisnih varijabli odstupaju statistički značajno od normalne distribucije, korišten je neparametrijski test, Mann-Whitneyev test za dva nezavisna uzorka, uz pet postotnu razinu rizika.

Tablica 2. Odabrani deskriptivni statistički pokazatelji analiziranih zavisnih varijabli učenika koji su u trenutku provođenja istraživanja završili četvrti ili peti razred osnovne škole $(\mathrm{N}=148)$

\begin{tabular}{|c|c|c|c|c|c|c|c|c|}
\hline & 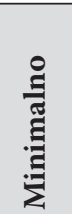 & 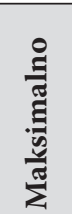 & $\mathbf{M}$ & SD & $\begin{array}{l}\text { K-S } \\
\text { test }\end{array}$ & $\mathbf{p}$ & 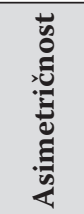 & 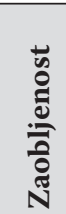 \\
\hline Matematika & 2 & 5 & 4,07 & 1,08 & 3,38 & $0,00^{*}$ & $-0,85$ & 0,62 \\
\hline $\begin{array}{c}\text { Hrvatski } \\
\text { jezik }\end{array}$ & 2 & 5 & 4,53 & 0,70 & 4,72 & $0,00^{*}$ & $-1,67$ & 2,91 \\
\hline $\begin{array}{c}\text { Prosjek } \\
\text { ocjena }\end{array}$ & 3,27 & 5,00 & 4,61 & 0,49 & 2,58 & $0,00^{*}$ & $-1,20$ & 0,27 \\
\hline
\end{tabular}

Legenda: M - aritmetička sredina; SD - standardna devijacija; K-S test - koeficijent Kolmogorov-Smirnovljeva Z testa; p - razina statističke značajnosti Kolmogorov-Smirnovljeva testa; * - statistički značajan koeficijent na razini značajnosti $p<0,05$, Asimetričnost koeficijent simetričnosti distribucije rezultata; Zaobljenost - koeficijent oblika distribucije rezultata

Koristeći Mann-Whitneyev test za dva nezavisna uzorka, uz pet postotnu razinu rizika, testirano je postojanje statistički značajnih razlika u referentnim ocjenama između učenika četvrtih i petih razreda koji su tijekom prva tri razreda pohađali produženi boravak te onih koji tijekom prva tri razreda nisu pohađali boravak. Utvrđeno je da se učenici četvrtih i petih razreda koji su tijekom prva tri razreda pohađali boravak, statistički značajno razlikuju od onih koji ga nisu pohađali. Učenici četvrtih i petih razreda koji su tijekom prva tri razreda pohađali boravak, na kraju školske godine postižu bolje ocjene iz hrvatskog (Mann-Whitney $\mathrm{U}=1884,50 ; \mathrm{p}=0,01$ ), matematike (Mann-Whitney $\mathrm{U}=1646,50 ; \mathrm{p}=0,00)$ te postižu bolji prosjek svih ocjena na kraju šk. godine (Mann-Whitney $U=1687,00 ; p=0,00$ ), na razini statističke značajnosti od 0,05. Usporedbom rangova analiziranih skupina, vidljivo je da učenici četvrtih i petih razreda koji su prva tri razreda pohađali boravak, imaju bolje ocjene iz hrvatskog i matematike te veći prosjek svih ocjena na kraju školske godine, dok oni koji nisu pohađali boravak, imaju lošije ocjene iz hrvatskog i matematike te lošiji prosjek svih ocjena na kraju školske godine. 


\section{Rasprava}

S obzirom na dobivene rezultate, prihvaćanje prve hipoteze potencijalno je objašnjivo pretpostavkom da učenici koji pohađaju boravak stječu bolje radne navike te uz pomoć učitelja iz produženog boravka uspješnije rješavaju zadaće i usvajaju nastavne sadržaje.

Rezultati ovog istraživanja na tragu su rezultata ranijeg istraživanja ove tematike na uzorku učenika romske nacionalne manjine. Rezultati istraživanja uloge produženog boravka na uspjeh učenika romske nacionalne manjine upućuju na to da program produženog boravka pozitivno djeluje na uspjeh učenika romske manjine te da ih treba što ranije i što duže imati uključene u produženi boravak. ${ }^{25}$

Istraživanje je pokazalo da, osim što učenici koji pohađaju produženi boravak imaju bolji školski uspjeh u odnosu na svoje vršnjake koji ne idu u boravak, nego i da bolji školski uspjeh zadržavaju u četvrtom i petom razredu. Navedeno je potencijalno objašnjivo pretpostavkom da učenici pozitivne navike stečene u prva tri razreda pohađajući produženi boravak, zadržavaju i u četvrtom te petom razredu. Valja napomenuti da su matematika i hrvatski jezik školski predmeti za koje je specifičan veći broj domaćih zadaća pa ne čudi da učenici iz boravka bolje ocjene iz tih predmeta zadržavaju i u četvrtom te petom razredu, za razliku od svojih vršnjaka koji nisu pohađali boravak. Budući da učenici koji pohađaju boravak, nakon vremena predviđenog za redovnu nastavu ostaju u školi i uz prisutnost učitelja rješavaju školske zadaće, zbog specifičnih uvjeta rada, vjerojatno razvijaju bolje radne navike i disciplinu, nego djeca koja ga ne pohađaju. Pod specifičnim uvjetima rada podrazumijevaju se oni uvjeti koje djeca uz prisutnost razrednih kolega i svog učitelja imaju u produženom boravku, u odnosu na djecu koja školske zadaće obavljaju kod kuće u obiteljskoj atmosferi. Djeca u boravku zadaće pišu u vrijeme previđeno baš za to, bez ometanja, prekidanja, obavljanja nekih drugih nepredviđenih aktivnosti s čime se susreću ona djeca koja zadaće pišu u kućnoj, obiteljskoj atmosferi. Vjerojatnije učenici u boravku, u aktivnoj razrednoj atmosferi i pod paskom autoriteta učitelja, postižu bolju koncentraciju pri obavljanju zadaće i time stječu kvalitetnije radne navike.

Pretpostavka je da ta djeca dolaze kući zadovoljnija, s već završenim i pregledanim zadaćama pa se onda mogu posvetiti igri, zabavi i kvalitetnom provođenju vremena s roditeljima i drugim članovima obitelji. Djeca koja ne pohađaju boravak, kući dolaze s obvezom i teretom obavljanja školskih zadataka i

\footnotetext{
${ }^{25}$ Usp. A. TONKOVIĆ, E. GLAVAŠ, M. LONČAR, Uloga produženog boravka na uspjeh učenika romske nacionalne manjine, u: Adrijana VIŠNJIĆ-JEVTIĆ i dr. (ur.), Jezik, književnost i obrazovanje - suvremeni koncepti. Zbornik radova s međunarodnog znanstvenog skupa 4. međimurski filološki i pedagoški dani, Čakovec, Učiteljski fakultet Sveučilišta u Zagrebu, 2020, 299-317, 299.
} 
nije im uvijek jednostavno napraviti kvalitetan raspored koji će zadovoljiti sve njihove potrebe i omogućiti im da u miru, bez stresa naprave školske zadaće, a da pritom dio vremena provedu u igri i druženju s članovima obitelji. Nameće se pretpostavka da oni stječu bolje radne navike u odnosu na djecu koja ne idu u boravak.

Ranije istraživanje pokazuje da je ono što učitelji misle i čine s domaćom zadaćom povezano $\mathrm{s}$ ulaganjem učenikovih napora i emocija u izvršavanje domaćih zadaća, kao i ostvarenjem njegovih postignuća. ${ }^{26}$

Na važnost radnih navika kod djece ukazuje i istraživanje čiji rezultati upućuju na to da razvijanje tih navika kod djece može imati važan utjecaj na njihova akademska postignuća u odrasloj dobi. ${ }^{27}$

Da učenici u produženom boravku imaju mirnije ozračje za izvršavanje domaćih zadaća ukazuju rezultati istraživanja prema kojima djeca često pokazuju negativne emocija prilikom pisanja domaćih zadaća kod kuće, a roditeljima je stresno proživljavati njihove osjećaje dok obavljaju zadane zadatke i pri tom držati svoje osjećaje pod kontrolom..$^{28}$ Budući da je učenikovo opterećenje nastavom među važnijim čimbenicima razredno-nastavnog ozračja, ${ }^{29}$ ono koje se ostvaruje u programu produženog boravka učenicima bi trebalo biti opuštenije i ugodnije u odnosu na redovnu nastavu jer u boravku nisu opterećeni usvajanjem novih nastavnih sadržaja, ispitivanjima i pisanjem testova. Sve to upućuje na moguće razloge zašto učenici koji pohađaju program produženog boravka postižu boji školski uspjeh u odnosu na svoje vršnjake koji ga ne pohađaju.

U nekom budućem istraživanju moglo bi se ispitati povezanost pohađanja programa produženog boravka i školskog uspjeha u višim razredima osnovne škole.

\section{Zaključak}

Cilj ovog istraživanja bio je ispitati razlike u školskom uspjehu učenika osnovne škole s obzirom na pohađanje programa produženog boravka. Budući da je istraživanje provedeno na prigodnom uzorku, mogućnost generalizacije istraživačkih zaključaka i tendencija uočenih u okviru istraživačkog uzorka na referentnu populaciju je ograničena.

${ }^{26}$ Usp. U. TRAUTWEIN i dr., Between-Teacher Differences in Homework Assigments and the Development of Student's Homework Effort, Homework Emotions and Achievement, Journal of Educational Psychology, 101 (2009) 1, 176-189, 184.

${ }^{27}$ Usp. S. D. SIMPKINS i dr., Children's Developing Work Habits From Middle Childhood to Early Adolescence. Cascading Effects for Academic Outcomes in Adolescence and Adulthood, Developmental Psychology, 56 (2020) 12, 2281-2292, 2291.

${ }^{28}$ Usp. J. CUNCHA i dr., Parents' Conceptions of their Homework Involment in Elementary School, Psicothema, 27 (2015) 2, 159-165, 163.

${ }^{29}$ Usp. M. JURAČIĆ, Učenikovo opterećenje nastavom i razredno-nastavno ozračje, Odgojne znanosti, 8 (2006) 2, 329-346, 329. 
Zbog svoje specifične forme u odnosu na redovnu razrednu nastavu, produženi boravak omogućava učiteljima širok izbor aktivnosti kojima realiziraju okvirno zadane ciljeve kurikularnih dokumenata. Rezultati ovog istraživanja mogli bi potaknuti na razmišljanje o omogućavanju dostupnosti programa produženog boravka svoj djeci, neovisno o zaposlenosti roditelja. Budući da rezultati ukazuju da boravak pozitivno utječe na školski uspjeh, a radi dobrobiti samih učenika, bilo bi korisno da se u njega mogu bezuvjetno upisati svi učenici koji to žele.

Budući da učenici iz naše zemlje postižu ispodprosječne rezultate na PISA testiranjima, ${ }^{30}$ a i po broju nastavnih sati u školskoj godini ${ }^{31}$ smo ispod prosjeka, način da učenici nakon redovne nastave ostaju u školi i u okviru boravka imaju organizirano vrijeme za rješavanje zadaća, za provođenje raznih aktivnosti i za sport, svakako može biti smjernica i za organiziranje cjelodnevne nastave $u$ osnovnim školama.

Kao zemlja se trebamo uspoređivati s uspješnijima i boljima od sebe te našim učenicima osigurati uvjete i resurse za provođenje nastave koja će rezultirati vrhunskim obrazovnim postignućima.

\footnotetext{
${ }^{30}$ OECD, PISA 2018 country-specific overviews (all participants), https:/www.oecd.org/pisa/ publications/pisa-2018-snapshots.htm (10.11.2020).

${ }^{31}$ Usp. European Commission/AECEA/Euridice, Recommended Annual Instruction Time in Full-time Compulsory Education in Europe-2018/19. Eurydice-Facts and Figures. Luxemburg: Publications Office of the European Union, 2019, 8.
} 
Ivana Olujić* - Nevenka Maras**:

The Differences in School Achievement of Lower-Grade Elementary School Students Depending on Whether they Attend the Extended School Day Program

\section{Summary}

The extended school day program is a special form of educational work with lower-grade elementary school students. The aim of this survey was to determine the differences in students' school achievement, depending on whether they attend the extended school day program or not. The survey included 386 first- to fifth-grade students $(\mathrm{N}=386)$ in the Većeslav Holjevac Elementary School in Zagreb. For the purposes of this paper, a secondary data source was used, i.e. pedagogical research results. Grades in the Croatian language, mathematics and the grade point average at the end of the 2017/2018 school year were assessed, as well as attendance of the extended school day program. The results of the survey indicate that students who attend the extended school day program in the first three grades achieve statistically significantly better grades in the Croatian language $(0,00)$ mathematics $(0,03)$ and have a better grade point average $(0,00)$ than students who do not attend the program. Furthermore, the results indicate that students who attended the extended school day program retain better grades in the fourth and fifth grade, compared to their peers who did not attend the program. The results certainly encourage reflection on the availability of extended school day program to all students who are interested in attending it, regardless of their parents' working hours.

Key words: elementary school, extended school day program, grades, school achievement, students.

(na engl. prev. Željka Gorički)

\footnotetext{
* Ivana Olujić, Mag. Educ. Philol. Croat., Ministry of Science and Education; Address: Donje Svetice 38, HR-10000 Zagreb, Croatia; E-mail: iolujic81@gmail.com.

**Nevenka Maras, PhD, Asst. Prof., University of Zagreb, Faculty of Teacher Education; Address: Savska cesta 77, HR-10000 Zagreb, Croatia; E-mail: Nevenka871@gmail.com.
} 